\title{
La palabra empeñada Iluminar con la cámara la oscuridad de la historia
}

\author{
Pablo Mariano Russo \\ Universidad de Buenos Aires \\ pablomarianorusso@gmail.com
}

\begin{abstract}
Que su nombre siga casi tan ignorado en su decir, desde su encuentro con Ernesto país como el pedazo de selva que esconde sus huesos era previsible para Jorge Masetti. Periodista, sabía cómo se construyen renombres y se tejen olvidos. Guerrillero, pudo presumir que si era derrotado el enemigo sería el dueño momentáneo de su historia. Che Guevara y Fidel Castro en la Sierra Maestra en el año 1958, hasta su desaparición en la selva salteña a fines de abril de 1964, cuando lideraba el Ejército Guerrillero del Pueblo bajo el nombre de Comandante Segundo.
\end{abstract}

Rodolfo Walsh, del prólogo de 1969 al libro de Jorge Masetti, Los que luchan y los que lloran.

La palabra empeñada (Argentina, 2010) es un largometraje documental de noventa minutos, realizado por Juan Pablo Ruiz y Martín Masetti, sobre los últimos años de la vida del periodista y guerrillero Jorge Ricardo Masetti (I929-I964?). Es

Lo primero que salta a la vista es que uno de los directores lleva el mismo apellido que el personaje en torno a quien giran los variados testimonios de la película. No es una mera coincidencia: Martín es nieto de Jorge Masetti, lo cual constituye un dato no menor a pesar de que La palabra empeñada no esté narrada desde su propia subjetividad ni en primera persona, sino que está estructura como un documental «tradicional». Ya 


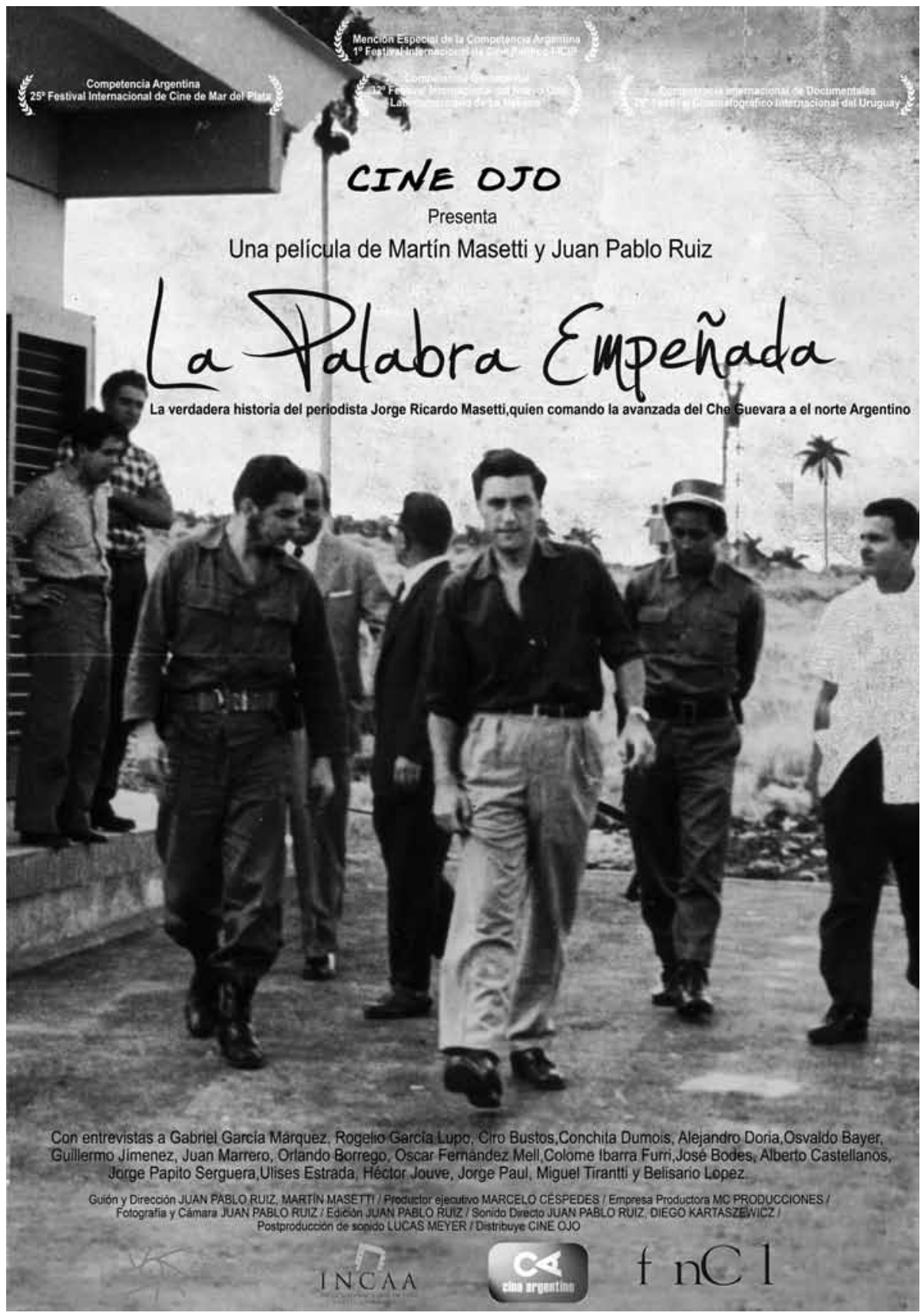


volveremos sobre esto, pero primero intentemos responder someramente a la pregunta: ¿quién fue Jorge Masetti?

Jorge Ricardo Masetti tuvo una corta pero intensa existencia: nació el 3I de mayo de 1929 en Avellaneda, y la última vez que lo vieron sus compañeros guerrilleros fue al borde del río Piedras, en la selva salteña del departamento de Orán. Entonces era el jefe al mando del EGP, la primera guerrilla guevarista del país. A mediados de los años cuarenta, luego de probarse como jugador de fútbol en el Racing Club y de grabar algunos clásicos tangos de Carlos Gardel y Alfredo Le Pera, el joven Masetti se inició en el periodismo: trabajó en el diario Tribuna, luego en Noticias Gráficas y Clarín, y en las radio Excelsior y El Mundo. Cuando era jefe de la sección de internacionales de El Mundo viajó a Cuba para entrevistar a Fidel Castro y al Che Guevara antes del triunfo de la revolución. De ese encuentro nacería su maravilloso relato Los que luchan y los que lloran. Un año más tarde, Masetti volvió a Cuba invitado por el Che para fundar y dirigir la agencia de noticias Prensa Latina, donde tuvo como compañeros de trabajo a Rodolfo Walsh y a Gabriel García Márquez, y las colaboraciones de Jean Paul Sartre y Simone de Beauvoir, entre otros intelectuales comprometidos. Forjó una intensa amistad con el Che Guevara, y sus coincidencias ideológicas y prácticas lo llevaron a liderar el intento revolucio- nario en la Argentina, a principio de los años sesenta. Al igual que el Che, Masetti cambió la comodidad de La Habana por la selva sudamericana, y murió cuando aún no había cumplido los 35 años. A diferencia del Che, su cuerpo aún no fue encontrado.

Hechas las presentaciones, volvamos al trabajo de la dupla Ruiz-Masetti. Como señalamos, este documental no integra el corpus de discursos audiovisuales conocidos como "narrativas del yo» (Los rubios, de Albertina Carri; $M$, de Martín Prividera, Papá Iván, de María Inés Roqué, por citar algunos ejemplos), en la que predomina la subjetividad explícita del realizador presente en la pantalla. Pero, a pesar de construirse como un documental convencional que gira en torno a los testimonios de los entrevistados, es inevitable asociar esta narración fílmica con varios elementos que no están explícitamente en la película. Uno de ellos es la relación familiar (de identidad) que señalamos entre Jorge, personaje y objeto del documental, y Martín, uno de los autores del discurso audiovisual. Martín Masetti cuenta que «éste es un documental testimonial bien clásico, porque nos parecía que lo importante era focalizar en la historia de Masetti, que es una historia muy atractiva. Si nosotros hacíamos un doble relato (el de la historia de vida de él y el de mis impresiones a medida que íbamos investigando la historia), se iba a perder el foco de lo que queríamos con- 
tar, que eran sus últimos años. Eso es lo que nos motivó a hacer la película. Esta historia tenía un sustento, merecía ser contada en formato documental» (Russo y Perea, 20II:I).

La palabra empeñada está estructurado en tres partes: I) Masetti periodista; 2) Comandante Segundo; y 3) Revolución en la Argentina. En cada una de ellas, los testimonios van rescatando y re-construyendo la figura de Jorge Masetti a partir de una pluralidad de memorias, sin ningún relato en off que las ordene o les de contexto. Entre los entrevistados, podemos ver y oír a compañeros de Masetti de Prensa Latina en Cuba, de la lucha armada en la Argentina, y otros compañeros de ruta: Gabriel García Márquez, Rogelio García Lupo, Ciro Bustos, Alejandro Doria, Alberto Castellanos y Conchita Dumois, su segunda mujer, son algunos de ellos. Esta recopilación de voces (en total, los realizadores tienen más de sesenta horas de testimonios que debieron editar para la hora y media de duración final) les implicó cuatro arduos años de investigación. Sin lugar a dudas, el gran valor de este trabajo autodidacta es la calidad de las entrevistas conseguidas, e indudablemente el apellido de uno de los directores fue una llave fundamental para abrir algunas puertas. El relato se complementa con material de archivo (audios de la entrevista al Che y a Fidel Castro en la Sierra Maestra, imágenes de Prensa Latina), e imágenes aéreas de la espesa selva de Orán.
Las palabras de quienes conocieron y compartieron la vida de Masetti son utilizadas como argumentos para una lectura del pasado, que puede erigirse como contrapuesta a otras versiones oficiales de la historia. Como sostiene Gustavo Aprea, a través de la combinación entre imágenes de archivo fácilmente reconocibles y el relato de la experiencia de los sobrevivientes y sus consecuencias traumáticas, se logra un alto grado de verosimilitud en el relato (Aprea, 2008:8I). Esta idea se aplica concretamente a la segunda y tercer parte del documental, centradas en la construcción del Masetti guerillero.

Como dijimos antes, existe una relación insoslayable entre el texto fílmico y algunos discursos externos. Entre estos discursos se cuenta el debate desatado tiempo atrás a partir de la publicación de una entrevista a Héctor Jouvé (miembro del EGP, que también brinda testimonio en el documental) en la revista $\mathrm{La}$ Intemperie, en los números de octubre y noviembre del año 2004. En esa entrevista, Jouvé relata el fusilamiento interno de dos miembros de la guerrilla: Adolfo Rotblat y Bernardo Groswald. Sus declaraciones generaron diferentes reacciones que comenzaron con una carta de Oscar del Barco y siguieron con argumentos publicados en diferentes revistas (Conjetral, Confines, Lucha Armada, Acontecimiento, El Ojo Mocho...). Gran parte de estos textos y cartas fue compilada luego en 


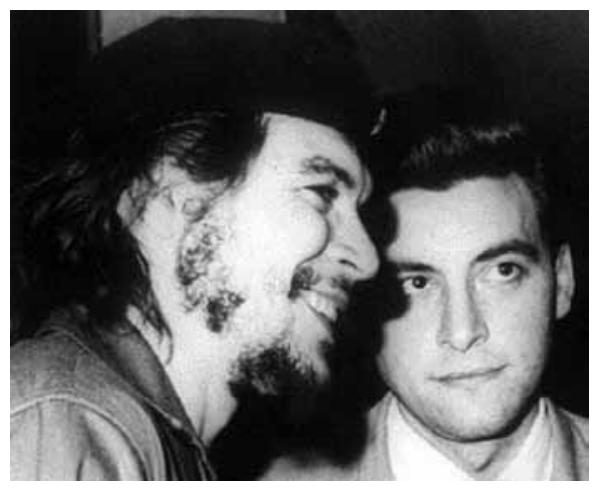

la publicación de los dos tomos de $N o$ matar. Sobre la responsabilidad.

En cuanto a este debate, en La palabra empeñada éste está implícito: no hay una puesta en contexto ni definición del hecho, a pesar de que algunos compañeros de guerrilla de Jorge Masetti opinan sobre el tema en la película. Martín Masetti explicá por qué: «Hay muchas cosas que se dan por sobreentendidas (en la película), el sectarismo en Cuba en la época de Prensa Latina es una de ellas. Pero fue una decisión, sino teníamos que caer en la disposición de hacer un documental más didáctico, y sabemos que la película es para la gente que está más o menos interiorizada con el tema» (Russo y Perea, 20II:2). En el documental hay dos posiciones: un testimonio sostiene que a esos dos compañeros los tendrían que haber evacuado de la selva; y otro testimonio resalta el estado de quiebre físico y mental insalvable en el que se encontraban estos dos guerrilleros.
La palabra empeñada instala su discurso claro y directo entre cantidades de voces que retoman el pasado con la intención de neutralizarlo. Ruiz y Masetti no buscan develar ningún misterio ni resolver enigmas, pero si logran echar luz sobre una figura marginad y olvidada en la historia de héroes Latinoamericanos. El pasado, como sostiene Michael Löwy en su libro sobre las Tesis de la filosofía de la historia de Walter Benjamin, sólo puede comprenderse a la luz del presente, y su verdadera imagen es fugaz y precaria, «como un relámpago» (Löwy, 2002:54). El retrato de Jorge Masetti que construyen los testimonios de este documental destaca por sobre todo el empuje, la entrega, la valentía, y el compromiso de su protagonista con la causa revolucionaria, sin por esto caer en una mistificación del pasado ni en una abstracción de la historia. Como afirma John Berger, el pasado nunca está ahí esperando que lo 
descubran, ni es algo para vivir en él, sino un pozo de conclusiones del que extraemos para actuar. Es el miedo al presente el que lleva a la mistificación del pasado. De allí que una persona o una clase que es aislada de su propio pasado tenga menos libertad para decidir o actuar que una persona o una clase que ha sido capaz de situarse a sí mismo en la historia (Berger, 2000:42). Bienvenida entonces esta semblanza posible del periodista y guerrillero, esta primera aproximación necesaria para rescatar a Jorge Masetti del tejido del olvido.

Bibliografía

- APREA, Gustavo (2008). Cine y políticas en Argentina. Continuidades y discontinuidades en 25 años de democracia. Los Polvorines: Universidad de General Sarmiento.

• BELZAGUI, Pablo René (ed.) (2007). No matar. Sobre la responsabilidad. Universidad Nacional de Córdoba: Ediciones del cíclope. - BERGER, John y otros (2002). Modos de ver. Barcelona: Gustavo Gili. - LÖWY, Michael (2002). Walter Benjamin: Aviso de incendio. Una lectura de las tesis "Sobre el concepto de historia." Buenos Aires: Fondo de Cultura Económica..

- MASETTI, Jorge (2010). Los que luchan y los que lloran. La Habana. - ROT, Gabriel (2010). Los orígenes perdidos de la guerrilla en la Argentina. Buenos Aires: Waldhuter.

- RUSSO, Pablo y PEREA, Lucas (2011). «Entrevista a Martín Masetti, director de La palabra empeñada." En Revista de cine latinoamericano Tierra en Trance. Buenos Aires. Disponible en: http://tierraentrance.miradas.net/2011/11/entrevistas/entrevista-a-martin-masetti-director-de-la-palabra-empenada.html 